I N S T I T U T O

$\mathrm{DE}$

M E D I C I N A

T R O P I C A L

$\mathrm{DE}$

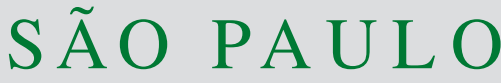

JOURNAL OF THE SÃO PAULO INSTITUTE OF TROPICAL MEDICINE

(1)Universidade Federal de Goiás, Instituto de Patologia Tropical e Saúde Pública, Laboratório de Estudos da Relação Parasito-Hospedeiro, Goiânia, Goiás, Brazil

(2)Universidade Federal de Goiás, Faculdade de Medicina, Hospital das Clínicas, Goiânia, Goiás, Brazil

Correspondence to: Ana Maria de Castro Universidade Federal de Goiás, Instituto de Patologia Tropical e Saúde Pública, Laboratório de Estudos da Relação Parasito-Hospedeiro, Rua 235, s/n, Setor Universitário, CEP 74605-050, Goiânia, GO, Brazil

Tel: +55 6232096113

Fax: +55 52 3209-6363

E-mail: amaria.ana@gmail.com

Received: 17 April 2017

Accepted: 7 June 2017
http://dx.doi.org/10.1590/S1678-9946201759063

\section{Nursing infant with acquired toxoplasmosis in the first months of life - a case report}

\author{
Hanstter Hallison Alves Rezende', Heloísa Ribeiro Storchilo', Jaqueline \\ Ataíde Silva Lima ${ }^{1}$, Antônio Roberto Gomes Júnior ${ }^{1}$, Taynara Cristina \\ Gomes ${ }^{1}$, Jéssica Yonara de Souza', Mariza Martins Avelino², Waldemar \\ Naves do Amaral'2, Marina Clare Vinaud', Ana Maria de Castro'1
}

\section{ABSTRACT}

Toxoplasmosis is caused by Toxoplasma gondii and the probability of this infection occurring in the first months of life is usually low because its transmission is related to eating habits. A 6-month-old nursing infant was diagnosed with acute toxoplasmosis, which was identified through anti-T. gondii $\operatorname{IgA}, \operatorname{IgM}$ and low-avidity IgG serologic assays, polymerase chain reaction (PCR) and mouse bioassay test although its mother was seronegative. This serological divergence between mother and child led us to interview the mother regarding epidemiological factors. During this interview, she reported that she had given her 2-monthold baby a piece of undercooked beef to suck on. After some time, the baby presented fever and cervical lymphadenitis. This report emphasizes the importance of serological surveys of toxoplasmosis in nursing infants presenting with fever and lymphadenitis, in view of the possible acquisition of toxoplasmosis in the first months of life.

KEYWORDS: Toxoplasma gondii. Nursing infant. Diagnostic.

\section{INTRODUCTION}

Toxoplasmosis is a zoonotic disease caused by the protozoan Toxoplasma gondii. The infection is usually acquired through the ingestion of food and/or water contaminated with parasite cysts or oocysts, or through a blood transfusion or by vertical transmission ${ }^{1}$.

In most cases, toxoplasmosis acquired by immunocompetent individuals is characterized by non-painful lymphadenitis of the cervical lymph nodes without other complaints ${ }^{2}$. Acquired toxoplasmosis is commonly related to eating habits, especially the ingestion of raw or undercooked meat containing cysts and bradyzoites, or the ingestion of raw vegetables contaminated with oocysts. Toxoplasmosis is rarely acquired in the first months of life because nursing infants should feed exclusively on breast milk ${ }^{3,4}$.

The diagnosis of toxoplasmosis is based on immunological assays for the detection of $\operatorname{IgA}$, IgE, IgM, IgG and IgG avidity. Parasitological assays such as the polymerase chain reaction (PCR) and mouse bioassay are also used to detect the presence of the parasite $2,5,6$ IgG antibodies are markers of chronic or late infection, while other antibodies such as $\operatorname{IgA}$, IgE and $\operatorname{IgM}$ are markers of a recent infection. However, the diagnostic confirmation of active infection is complex because IgM levels may remain significantly high for a period of more than 12 months, thus requiring the association with levels of other antibodies such as 
$\operatorname{IgA}, \operatorname{IgE}$ and $\operatorname{IgG}$ avidity $^{6-8}$. This study is a case report of acquired toxoplasmosis detected in a nursing infant in the first months of life.

\section{CASE DESCRIPTION}

The male nursing infant was born in April 14 ${ }^{\text {th }}$, 2016, underwent a newborn screening test at 7 days of age at the Nova Era Comprehensive Health Care Center (CAIS) in Aparecida de Goiânia, GO, Brazil. At that time, the newborn was asymptomatic and presented good health. Before the newborn screening collection procedure, the mother was invited to participate in a newborn toxoplasmosis survey conducted at the Federal University of Goiás (UFG), which involved the detection of toxoplasmosis through filter paper screening. The mother signed the consent form and was informed about the survey, as well as the need for a new blood collection within a period of a few months.

The newborn screening using filter paper tested negative for toxoplasmosis. Therefore, this newborn was selected for the negative control group. Six months after the first blood sampling, this mother and the baby were invited for the second blood collection in October, $19^{\text {th }}, 2016$. The mother presented negative anti-T. gondii $\operatorname{IgM}$ and $\operatorname{IgG}$ results, while the 6-month-old nursing infant tested positive for anti-T. gondii $\operatorname{IgA}$, IgM, had low-avidity IgG and positive PCR assay.

The divergent results of mother and child led us to collect additional blood samples in November, $18^{\text {th }}, 2016$ which confirmed the previous results. The mouse bioassay was performed on the leukocyte cream of the child's peripheral blood. A week after the inoculation of BALB/c mice, the animals presented clinical signs of infection such as lethargy and ruffled fur. The animals were euthanized and subjected to peritoneal lavage and the microscopy analysis of this material revealed the presence of $T$. gondii tachyzoites. A PCR was performed on the samples collected via peritoneal lavage and confirmed the $T$. gondii infection.

To determine how such a young nursing infant became infected, his mother was interviewed regarding epidemiological aspects. She stated that they did not have house pets such as dogs or cats, but these animals frequented the yard because her house was not enclosed by outer walls or fences. As for the child's feeding habits, his mother reported that he consumed only filtered water and breast milk. The mother then suddenly remembered attending a barbecue when her baby was 2 months old and that she had given him a piece of undercooked beef to suck on. After a certain interval of time, the child presented swollen lymph nodes and fever. The child's pediatrician attributed these signs to a viral infection, which progressed favorably.
After confirmation of the acquired toxoplasmosis, the nursing infant was sent to the Department of Pediatric Infectology at the UFG Clinical Hospital, where he was prescribed sulfadiazine (100 mg/kg/day, every 12 hours), pyrimethamine (1 mg/kg/day, once daily) and folinic acid $(10 \mathrm{mg} / \mathrm{day}$, every 3 days). The treatment was prescribed to last for one year. The child will undergo clinical follow-ups throughout his early childhood.

\section{DISCUSSION}

The detection of acquired toxoplasmosis in a 6-month-old nursing infant is very rare because exclusive breastfeeding represents a protective factor against contaminated food. Sucking on a piece of undercooked beef at two months of age was probably how toxoplasmosis was transmitted. This type of transmission in such a young infant has not yet been reported in the literature. The ingestion of contaminated water has been described as another infection route for nursing infants ${ }^{9}$. Another controversial factor is transmission through breast milk, which has not yet been proven ${ }^{10}$. In our case, this route was discarded because the mother remained seronegative throughout the entire period of investigation. This enabled us to confirm that the nursing infant acquired toxoplasmosis via exposure to contaminated food.

Factors associated with low socioeconomic and educational levels ${ }^{11}$ and with the ingestion of raw or undercooked meat are directly related to the risk of acquiring toxoplasmosis ${ }^{12-14}$. The mothers' knowledge of healthy eating habits and of the exclusive breastfeeding of nursing infants for the first six months of life, followed by predominant breastfeeding complemented with food until children are two years old, is extremely important to ensure their health and protect them from foodborne infections such as toxoplasmosis ${ }^{14-16}$. Infected infants should be monitored for a period of at least one year by means of periodic eye examinations and serology assays, as well as by the prescription of pyrimethamine, sulfadiazine and folinic acid $^{3,4}$.

\section{CONCLUSIONS}

Toxoplasmosis may be acquired by nursing infants in the first months of life if they are exposed to risk factors such as sucking on raw or undercooked meat. Confirmation of the infection was undertaken through molecular and serological analysis, which also enables to determine the phase of infection.

Health education preventive measures are needed to inform pregnant women and mothers on the importance of 
exclusive breastfeeding in nursing infants, given the lack of knowledge on the mode of transmission of toxoplasmosis and other foodborne infections that are risk factors for the child. It is important to carefully assess epidemiological information provided by patients and to carry out serological analyses to confirm toxoplasmosis in nursing infants, especially in cases presenting lymphadenitis accompanied by fever.

\section{ETHICAL APPROVAL}

This study was approved by the Research Ethics Committee of the Federal University of Goiás under the Protocol No 943.441.

\section{CONFLICTS OF INTERESTS}

The authors declare no conflict of interest.

\section{REFERENCES}

1. Gelaye W, Kebede T, Hailu A. High prevalence of antiToxoplasma antibodies and absence of Toxoplasma gondii infection risk factors among pregnant women attending routine antenatal care in two Hospitals of Addis Ababa, Ethiopia. Int J Infect Dis. 2015;34:41-5.

2. Carvalho CM, Farhat, CK. Toxoplasmose adquirida. J Pediatr. 1999;75 Supl 1:S63-7

3. Moncada PA, Montoya JG. Toxoplasmosis in the fetus and newborn: an update on prevalence, diagnosis and treatment. Expert Rev Anti Infect Ther. 2012;10:815-28.

4. Avelino MM, Amaral WN, Rodrigues IM, Rassi AR, Gomes MB, Costa TL, et al. Congenital toxoplasmosis and prenatal care state programs. BMC Infect Dis. 2014;14:33.

5. Montoya JG. Laboratory diagnosis of Toxoplasma gondii infection and toxoplasmosis. J Infect Dis. 2002;185 Suppl 1:S73-82.

6. Fonseca ZC, Rodrigues IM, Melo NC, Castro AM, Avelino MM. Importância do teste de avidez IgG na toxoplasmose congênita. Rev Patol Trop. 2016;45:42-54.
7. Liu Q, Wang ZD, Huang SY, Zhu XQ. Diagnosis of toxoplasmosis and typing of Toxoplasma gondii. Parasit Vectors. 2015;8:292.

8. Emelia O, Rahana AR, Mohamad Firdaus A, Cheng HS, Nursyairah MS, Fatinah AS, et al. IgG avidity assay: A tool for excluding acute toxoplasmosis in prolonged IgM titer sera from pregnant women. Trop Biomed. 2014;31:633-40.

9. Capobiango JD, Mitsuka-Breganó R, Monica TC, Ferreira FP, Reiche EM. Acute toxoplasmosis in a breastfed infant with possible transmission by water. Rev Inst Med Trop São Paulo. 2015;57:523-6.

10. Bonametti AM, Passos JN, Koga da Silva EM, Macedo ZS. Probable transmission of acute toxoplasmosis through breast feeding. J Trop Pediatr.1997;43:116.

11. Bollani, L, Stronati M. II neonato con toxoplasmosi congenita: clinica, terapia e follow-up. J Pediatr Neonat Individual Med. 2014;3:e030104.

12. Bonametti AM, Passos JN, Silva EM, Bortoliero AL. Surto de toxoplasmose aguda transmitida através da ingestão de carne crua de gado ovino. Rev Soc Bras Med Trop. 1997;30:21-5.

13. Avelino MM, Campos D Jr, Parada JB, Castro AM. Risk factors for Toxoplasma gondii infection in women of childbearing age. Braz J Infect Dis. 2004;8:164-74.

14. Brasil. Ministério da Saúde. Secretaria de vigilância em Saúde. Surto de toxoplasmose adquirida, Anápolis-GO, fevereiro de 2006. Bol Eletr Epidemiol. 2007;7:1-6. [cited 2017 July 18]. Available from: http://bvsms.saude.gov.br/bvs/periodicos/ boletim_eletronico_epi_ano07_n08.pdf

15. Dupont E, Dietrich MV, Frizzo RA, Ribeiro LE, Vitoria AM. Análise temporal do aleitamento materno em Unidade Básica de Saúde de Pelotas, Brasil. Rev Med (São Paulo). 2017;96:358.

16. Brasil. Ministério da Saúde. Secretaria de Atenção à Saúde. Departamento de Atenção Básica. Saúde da criança: crescimento e desenvolvimento. Brasília: Ministério da Saúde; 2012. (Cadernos de atenção básica; nº 33). 